\title{
TREATMENT OF INFECTIONS AND ANTIVIRAL AGENTS
}

\section{Treatment}

- of complicating infections

- of the virus itself

\section{Protozoal infections}

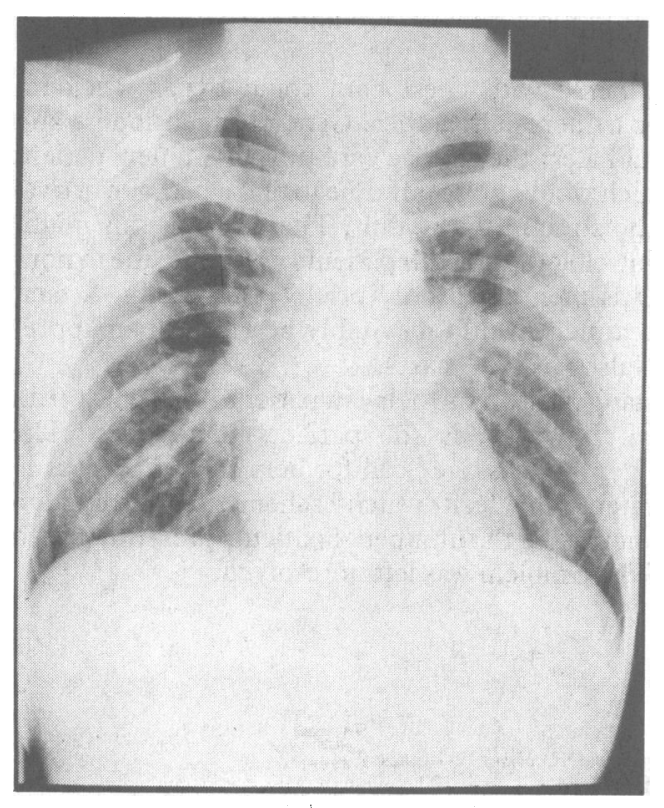

The treatment of human immunodeficiency virus (HIV) infection has been largely limited to the treatment of its complications-namely, the opportunistic tumours and infections. Most of the infections are due to reactivation of latent organisms in the host or in some cases to ubiquitous organisms to which we are continuously exposed. In general the treatment of these infections suppresses rather than eradicates the organisms, so relapse is common when treatment is stopped. The side effects of many of the drugs used do not easily permit the long term treatment that is needed.

Pneumocystis carinii pneumonia-High dose intravenous co-trimoxazole for three weeks remains a standard first choice regimen for treating $P$ carinii pneumonia, but once fever and symptoms have settled and blood gas values have improved the drug can be given by mouth from the second week. Side effects occur often, typically after seven to 10 days. Folinic acid (15 mg on alternate days) may be used to prevent cytopenia. If side effects are severe co-trimoxazole should be replaced by pentamidine. If possible this should be given by slow intravenous infusion to avoid hypotension and painful intramuscular sterile abscesses. Large controlled studies of prophylaxis have been conducted after first attacks of Pneumocystis carinii pneumonia in patients with the acquired immune deficiency syndrome (AIDS). Many doctors, however, use low dose co-trimoxazole two to four tablets daily or one tablet of pyrimethamine-sulphadoxine weekly (Fansidar), but sulphonamide sensitivity may be a problem with both these combinations. Monthly intramuscular pentamidine has also been used, and trials of pentamidine in an aerosol preparation are in progress.

\section{Protozoal infections}

\begin{tabular}{|c|c|c|c|c|c|}
\hline Infection & Drug & Dose & Duration & Route & Side effects \\
\hline $\begin{array}{l}\text { Pneumocystis carinii } \\
\text { pneumonia }\end{array}$ & Co-trimoxazole & $\begin{array}{c}20 \mathrm{mg} / \mathrm{kg} / \mathrm{day} \text { of } \\
\text { trimethoprim }\end{array}$ & 14-21 days & $\begin{array}{l}\text { Intravenous then } \\
\text { oral }\end{array}$ & $\begin{array}{l}\text { Nausea, fever, rash, } \\
\text { marrow suppression }\end{array}$ \\
\hline : & $\begin{array}{l}\text { Pentamidine } \\
\text { isethionate } \\
\text { Pentamidine } \\
\text { mesylate }\end{array}$ & $\begin{array}{l}4 \mathrm{mg} / \mathrm{kg} / \mathrm{day} \\
2.5 \mathrm{mg} / \mathrm{kg} / \text { day }\end{array}$ & $\begin{array}{l}\text { 14-21 days } \\
\text { 14-21 days }\end{array}$ & $\begin{array}{l}\text { Intravenous as slow } \\
\text { single daily } \\
\text { infusion }\end{array}$ & $\begin{array}{l}\text { Hypotension, hypoglycaemia, } \\
\text { renal failure, hepatitis, } \\
\text { marrow suppression }\end{array}$ \\
\hline Toxoplasmosis & $\begin{array}{l}\text { Sulphadiazine } \\
\text { Pyrimethamine } \\
\text { Clindamycin }\end{array}$ & $\begin{array}{l}2-4 \mathrm{~g} \text { daily } \\
25 \mathrm{mg} \text { daily } \\
500 \mathrm{mg} \text { four times } \\
\text { daily }\end{array}$ & $\begin{array}{l}\text { Indefinite } \\
\text { Indefinite } \\
\text { Indefinite }\end{array}$ & $\begin{array}{l}\text { Oral } \\
\text { Oral } \\
\text { Oral }\end{array}$ & As for sulphonamides \\
\hline Isosporiasis & Co-trimoxazole & $\begin{array}{l}2 \text { tablets four times } \\
\text { daily }\end{array}$ & Indefinite & Oral & As for sulphonamides \\
\hline
\end{tabular}


Toxoplasmosis-Cerebral toxoplasmosis is the commonest manifestation of toxoplasma infection. It responds well if treatment is started early, and a combination of sulphadiazine and pyrimethamine is the treatment of choice. Side effects may require stopping the sulphadiazine, but

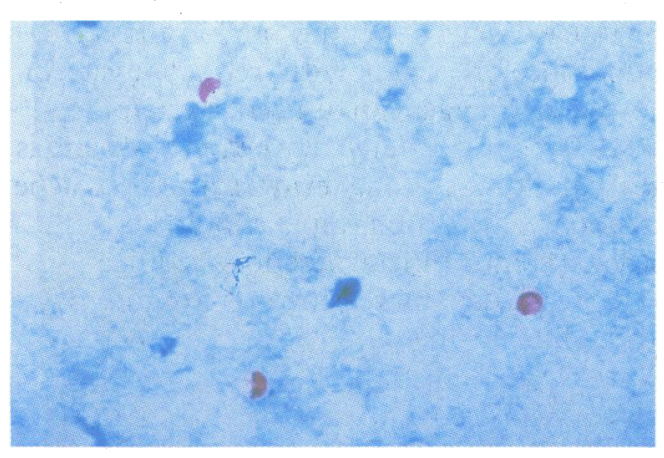
clindamycin has been used successfully as a substitute in uncontrolled studies. Dexamethasone is occasionally used in severe cases, in a short course, to reduce cerebral oedema. Relapse is common after treatment is stopped, and treatment should continue indefinitely.

Cryptosporidiosis - The reported successes with a variety of treatments are still anecdotal. Symptoms and excretion of cysts may be intermittent. Responses have been described after treatment with spiramycin $1 \mathrm{~g}$ orally four times a day and the lymphokine interleukin-2. Symptomatic treatment with codeine phosphate, loperamide, and other drugs may be the only effective measure. Isosporiasis responds well to co-trimoxazole, but relapses occur in half of all cases. Diarrhoea often occurs in the absence of recognised pathogens in the stool, and metronidazole has relieved symptoms in some cases.

\section{Viral infections}

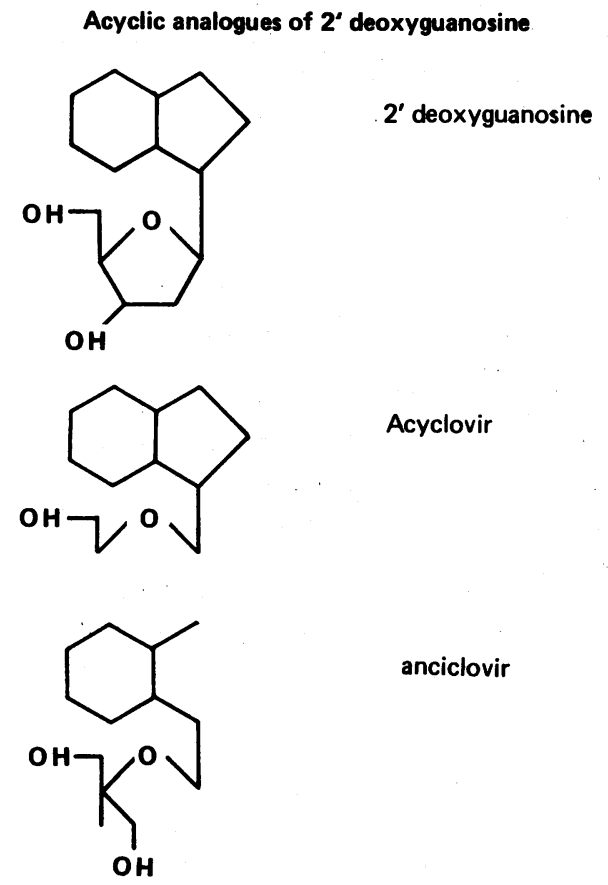

Severe mucocutaneous and systemic infections with herpes simplex viruses are best treated with acyclovir. Prophylaxis is used after severe infection and in patients with chronic HIV infection and increasing severity and frequency of recurrences. These recurrences can be a prelude to the chronic persistent mucocutaneous ulceration of AIDS. A lower frequency of doses than that recommended may adequately suppress reactivation of herpes simplex virus in some patients.

No trials of antiviral agents have been conducted in varicella zoster virus infections in patients with HIV infection. Dissemination of infection from dermatomal zoster is unusual. Intravenous and oral acyclovir have, however, been shown to benefit other immunocompromised patients.

Like acyclovir, ganciclovir is an acyclic analogue of deoxyguanosine. It has shown promising results in uncontrolled studies in the treatment of cytomegalovirus retinitis and to a lesser extent colitis. Patients with pneumonitis and encephalitis do not respond as well. In those with retinopathy it seems to delay the progression of disease, but maintenance treatment is required and even then relapse or progression may occur. Phosphonoformate (Foscarnet) has also been used in cytomegalovirus infections with some success. It is a pyrophosphate analogue and inhibits polymerase enzymes, but it has to be given as a continuous intravenous infusion. Intravenous treatment with both agents is a major drawback to antiviral maintenance treatment.

\section{Viral infections}

\begin{tabular}{|c|c|c|c|c|c|}
\hline Infection & Drug & Dose & Duration & Route & Side effects \\
\hline Herpes simplex & $\begin{array}{l}\text { Acyclovir } \\
\text { Acyclovir } \\
\text { Prophylaxis }\end{array}$ & $\begin{array}{l}5-10 \mathrm{mg} / \mathrm{kg} / 8 \text { hourly } \\
200 \mathrm{mg} / 5 \mathrm{times} \text { daily } \\
200 \mathrm{mg} \text { four times daily } \\
\text { (lower frequency possible) }\end{array}$ & $\begin{array}{l}10-14 \text { days } \\
10-14 \text { days } \\
? \text { Indefinite }\end{array}$ & $\begin{array}{l}\text { Intravenous } \\
\text { Oral } \\
\text { Oral }\end{array}$ & $\begin{array}{l}\text { Minimal } \\
\text { Minimal }\end{array}$ \\
\hline Varicella zoster & $\begin{array}{l}\text { Acyclovir } \\
\text { Acyclovir }\end{array}$ & $\begin{array}{l}10 \mathrm{mg} / \mathrm{kg} / 8 \text { hourly } \\
400 \mathrm{mg} \text { four times daily } \\
800 \mathrm{mg} \text { four times daily } \\
\text { being evaluated }\end{array}$ & $\begin{array}{l}10 \text { days } \\
10 \text { days }\end{array}$ & $\begin{array}{l}\text { Intravenous } \\
\text { Oral }\end{array}$ & $\begin{array}{l}\text { Minimal } \\
\text { Minimal }\end{array}$ \\
\hline Cytomegalovirus & $\begin{array}{l}\text { Ganciclovir } \\
\text { Maintenance } \\
\text { Phosphonoformate }\end{array}$ & $\begin{array}{l}2.5-5 \mathrm{mg} / \mathrm{kg} / 8 \mathrm{hourly} \\
2.5-5 \mathrm{mg} / \mathrm{kg} / \mathrm{probably} \text { daily } \\
0.05-0.16 \mathrm{mg} / \mathrm{kg} / \mathrm{min}\end{array}$ & $\begin{array}{l}\text { 14-21 days } \\
\text { Indefinite } \\
\text { 14-21 days }\end{array}$ & $\begin{array}{l}\text { Intravenous } \\
\text { Intravenous } \\
\text { Intravenous constant } \\
\text { infusion }\end{array}$ & $\begin{array}{l}\text { Marrow suppression } \\
\text { Marrow suppression } \\
\text { Renal impairment } \\
\text { bone accumulation }\end{array}$ \\
\hline
\end{tabular}




\section{Fungal infections}

Dermatophytic infections-imidazole creams

Oral candida - nystatin or amphotericin

Oesophageal candidiasis-ketoconazole

Systemic infections-amphotericin
Dermatophytic fungal infections respond well to imidazole creams. Oral candida is often asymptomatic in its early stages and may not require treatment. In more severe infections local treatment with frequent nystatin suspension or pastilles or amphotericin lozenges can be used. Systemic treatment with ketoconazole $200-400 \mathrm{mg}$ orally daily may be required and is the drug of choice for oesophageal candidiasis. Long term treatment may be required to prevent recurrences, and liver function values should be monitored. Cryptococcal and other systemic fungal infections require treatment with amphotericin $0.25 \mathrm{mg} / \mathrm{kg} / \mathrm{day}$, increasing to $0.5 \mathrm{mg} / \mathrm{kg} / \mathrm{day}$, for at least six weeks with or without flucytosine.

Bacterial pneumonias and skin infections will respond to conventional antibiotics. Gum and periodontal disease respond to local treatment with antibacterial mouthwashes or oral metronidazole. Mycobacterium tuberculosis infections are treated conventionally. Mycobacterium avium intracellulare organisms are resistant to conventional treatment. In vitro sensitivity has been shown with ansamycin (a rifamycin derivative) and clofazimine (an antileprosy compound), but treatment of patients with disseminated infection has been largely unsuccessful. Until a specific treatment is found the exact pathogenic role of these organisms in the many clinical syndromes of AIDS will be difficult to elucidate. Salmonella infections respond to treatment with appropriate antibiotics, but relapses of enteritis or bacteraemia are common.

\section{Antiviral therapy}

\section{The ideal antiviral agent_-a tall order}

- Protects uninfected cells

- Reduces viral production from infected cells

- Specific

Orally absorbed

- Crosses blood-brain barrier

- No side effects
The ideal antiviral agent should be specific, orally absorbed, and cross the blood-brain barrier. It should also be free from adverse effects, since the best we can expect is suppression of viral replication; the problem of latently infected cells will remain. Theoretically, inhibition of productive viral replication may allow some recovery of immune function, perhaps encouraging regression of tumours and elimination of the conditions favouring opportunistic infections.

Various potential targets for antiviral treatment have been identified since we have gained a better understanding of the replicative cycle and molecular biology of HIV. Realistically, however, most of the current efforts are being focused on specific inhibitors of the HIV reverse transcriptase enzyme.

Small uncontrolled studies with suramin and antimoniotungstate (HPA 23) showed little benefit and the adverse effects were unacceptable. Phosphonoformate (Foscarnet) has been shown to inhibit reverse transcriptase activity in vitro. In small controlled clinical trials it has produced some inhibition of viral replication. Its major drawback is that it has to be given intravenously. Ribavirin inhibits HIV in vitro, and results from controlled studies of chronic HIV infection are awaited.

A second generation of reverse transcriptase inhibitors has arrived with a group of $2^{\prime} 3^{\prime}$ dideoxynucleoside analogues. $3^{\prime}$-Azido-3' deoxythymidine (zidovudine, formerly azidothymidine, AZT) has considerable in vitro activity against HIV. It is a competitive inhibitor of reverse transcriptase and a DNA chain terminator.

The normal 2' deoxynucleosides which are substrates for DNA synthesis link to form a chain by phosphodiester linkages bridging the $5^{\prime}$ and $3^{\prime}$ positions on the five carbon sugar molecule. The $2^{\prime}$, 3 '-dideoxynucleoside analogues are formed by replacement of the 3'-hydroxy group by an azido, hydrogen, or other group. The HIV reverse
Blocking antibodies or ligands Viral "integrase" inhibitors products

Viral protein synthesis Viral budding
Enzyme inhibitors

Interferons (also act at other sites of

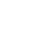

$\begin{array}{ll}\text { Target } & \text { Treatment } \\ \begin{array}{l}\text { Virus receptor } \\ \text { Uncoating of virus } \\ \text { Reverse transcriptase } \\ \text { RNAase }\end{array} & \begin{array}{l}\text { Blocking antibodies or ligands } \\ \text { Amantadine-like compounds } \\ \text { Inhibitors/DNA chain terminators } \\ \text { Integration }\end{array} \\ \begin{array}{l}\text { Inibitors } \\ \text { Viral gene expression "integrase" inhibitors } \\ \text { Inhibitors of HIV regulator genes and their } \\ \text { products }\end{array} \\ \begin{array}{l}\text { Enzyme inhibitors } \\ \text { and assembly }\end{array} \\ \begin{array}{l}\text { Viral budding } \\ \text { Interferons (also act at other sites of } \\ \text { replication cycle), antibodies, and }\end{array} \\ \text { ligands }\end{array}$




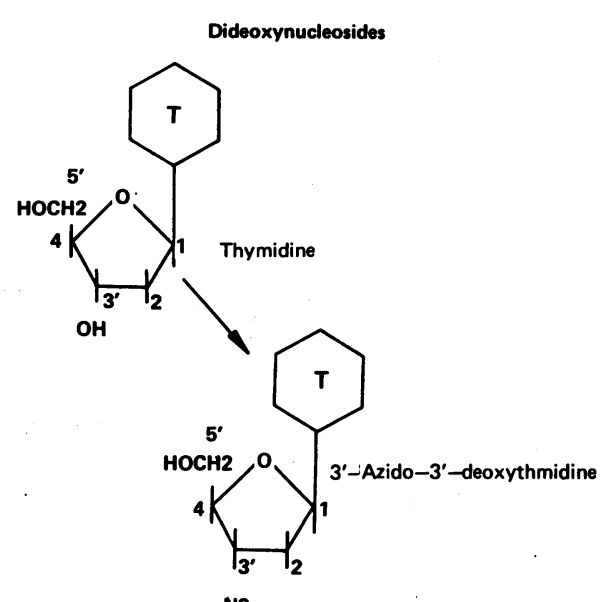

N3

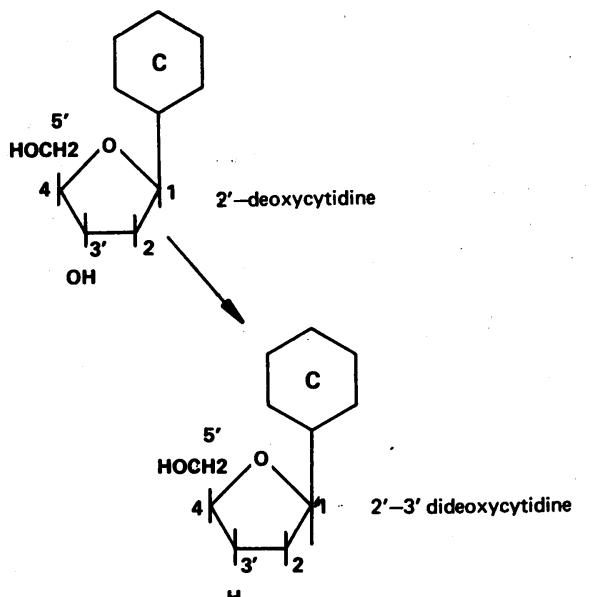

H transcriptase enzyme will add these nucleoside analogues to a growing HIV proviral DNA chain. Once inserted, the normal 5 ' to $3^{\prime}$ links will not occur, resulting in HIV proviral DNA chain termination.

Zidovudine is orally absorbed, and cerebrospinal fluid concentrations are about half of the corresponding plasma concentrations. In a double blind randomised controlled clinical trial of oral treatment $(250 \mathrm{mg}$ orally four hourly for six months) in 280 patients with past Pneumocystic carinii pneumonia or severe symptomatic chronic HIV infection (AIDS related complex) it significantly reduced mortality and morbidity and the number of episodes of opportunistic infection. There were significant improvements in some immunological variables, and a significant antiviral action was shown by a decrease in serum P24 (viral core protein). Small uncontrolled studies have shown improvement in neurological disease. Side effects include megaloblastic anaemia, neutropenia, nausea, insomnia, and myalgia. Dideoxycytidine is undergoing phase 1 studies, and preliminary data suggest that it is a more potent inhibitor of HIV on a molar basis and is less toxic.

Controlled trials of zidovudine and other antiviral agents are planned in asymptomatic patients with laboratory markers which predict more rapid progression to AIDS. The trials will assess these agents alone and in combination to reduce toxicity and improve efficacy. Because of the efficacy of zidovidine in patients with the AIDS related complex this will be used as an end point in such trials. If the drug is found to be beneficial in this condition and if side effects are minimal controlled trials will then be carried out very early in HIV infection, even at the point of seroconversion.

Future aims will be to combine not only antiviral agents but also antiviral and immunomodulatory therapies (if effective and beneficial examples of these are found).in large placebo controlled trials. Enhancement of the immune response to HIV may be one way of eradicating the virus from some of its latent sites.

Dr Ian V D Weller, MD, MRCP, is Wellcome Trust senior lecturer in infectious diseases, Academic Department of Genitourinary Medicine, Middlesex Hospital and Medical School, London.

\section{MATERIA NON MEDICA}

\section{Les Misérables}

It was a dry and sunny May afternoon on a Tuesday 10 years back. In the leprosy rehabilitation clinic as an intern I was watching some of those grotesquely mutilated, vaguely human creatures passively waiting for their turn, with little expectations from anybody of anything. One of them, like many others, had both hands swollen, badly infected, really clawed with a few fingertips missing. After the usual check up condescendingly I asked, "What were you doing before this?" He paused, stared into my eyes, and calmly replied, "I was an artist, a professional artist."

I was stunned, as if thrown off the roof by the sudden realisation that these were people; people as human as mysetf or anybody else. They were down to a level of existence that was difficult to fathom. Nature had been so unkind to them that I did not know how to console them. In fact I did not have enough strength to meet his eyes, and almost painfully wished that he was telling a lie. Without informing anybody, I left the clinic.

"But this is not fair. You must grow up. You must be objective," exclaimed a close friend of mine later on in the day.

A long time has elapsed since then. I have grown up. I have seen hundreds of patients getting well and cheerfully leaving the hospital. I have looked after terminally ill patients with cancer, a schizophrenic friend, and a beautiful girl who died of rabies; treated children in status asthmaticus, doctors in hepatic coma, and a newly wed with traumatic paraplegia. I have seen victims, and perpetrators, of rape, suicide, and murder. In the course of all this I have caused and cured fear, hope, and despair.

And I have grown up. Now in 1987, when I read the newspaper at my breakfast table, with news such as "... in a certain refugee camp a few kilometres from the city, people are eating stray cats and dogs to remain alive, because food cannot be despatched to them because of a barricade by other human beings," I am not stunned. I glance through the newspapers with my customary speed and proceed towards the clinic.-SHYAM SUNDER KOTHARI, consultant cardiologist, Vellore, India.

What treatment is advised for persistent abacterial chronic prostatitis?

Diagnosing chronic bacterial prostatitis is not difficult as it is invariably associated with recurrent bacteriuria. The prostate can be proved to be the site of bacterial infection even between episodes of bacteriuria when the patient is symptomless if segmented urine cultures are obtained. ${ }^{1}$ Nonbacterial prostatitis is more common than true bacterial prostatitis and is of obscure aetiology. Such patients do have inflammatory cells in urine voided after prostatic massage, but antimicrobial agents are ineffective. ${ }^{2}$ Treatment is largely empirical and symptomatic. Non-steroidal anti-inflammatory agents may be of benefit and phenazopyridine hydrochloride is often prescribed. Many patients with a vague aching discomfort in the suprapubic region or perineum, often radiating to the testes, and with discomfort on voiding are labelled as having prostatitis but do not produce prostatic secretions on massage or inflammatory cells in their urine voided after prostatic massage. The symptom complex is often stress mediated and sometimes associated with urgency and frequency of micturition or psychosexual difficulties. Getting the patient to.appreciate the likely mechanism of his problem is important in treatment, which may require several careful counselling sessions and antidepressant medication when appropriate.- $\mathrm{J} \mathrm{C}$ GINGELL, consultant urologist and lecturer in urology, Bristol.

1 Mears EM, Stamey TA. Bacteriologic localisation patterns in bacterial prostatitis and urethritis. Investigative Urology 1968;5:492-518. 2 Stamey TA. Prostatitis. I R Soc Med 1981;74:22-40. 